\title{
Chemical characterization of ambient suspended particles in an urban area affected by industrial activities
}

\author{
A. V. Silva ${ }^{1}$, S. M. Almeida ${ }^{1}$, C. M. Oliveira ${ }^{2}$ \& A. M. Miranda ${ }^{3}$ \\ ${ }^{1}$ URSN, IST/ITN, Instituto Superior Técnico, \\ Universidade Técnica de Lisboa, Portugal \\ ${ }^{2} C C M M-D Q B$, Faculdade de Ciências da Universidade de Lisboa, \\ Portugal \\ ${ }^{3}$ CESAM, Universidade de Aveiro, Portugal
}

\begin{abstract}
Urban areas are affected not only by road traffic but also by industrial activities that are frequently located close to cities. As these areas contain large concentrations of people, they exhibit both the highest levels of pollution and the largest targets of impact. Several reports revealed significant correlations between particulate matter (PM) levels and increased respiratory and cardiovascular diseases or mortality. Consequently, understanding and controlling air pollution in these areas is then important to identify mitigation actions to improve the air quality.

The main objectives of this study were to perform a chemical characterization of particulate matter $\left(\mathrm{PM}_{2.5}\right.$ and $\left.\mathrm{PM}_{2.5-10}\right)$ sampled in Setúbal - Portugal, to analyse seasonal trends and to identify sources and formation mechanisms of particles.

$\mathrm{PM}_{2.5}$ and $\mathrm{PM}_{2.5-10}$ were collected in a monitoring station, classified as urban traffic, in the winter and summer of 2011. Sampling was performed on a $12 \mathrm{~h}$ basis using a Gent sampler. The exposed nuclepore filters were measured by gravimetry and cut into two parts: one for element characterization using Instrumental Neutron Activation Analysis and the other for the water soluble ions determination by Ion Chromatography.

Source apportionment was performed by integrating time variability, night and day comparisons, enrichment factors, fine to coarse ratios and principal
\end{abstract}


component analysis. These approaches identified the emission sources: sea, soil, secondary aerosol, combustion and traffic.

Keywords: urban aerosols, PM, water soluble inorganic ions, trace elements.

\section{Introduction}

Aerosols are complex mixtures of liquid and solid particles directly emitted from anthropogenic as well as natural sources, or formed in the atmosphere by chemical reactions and condensation processes of gaseous precursors.

According to recent studies, Particulate Matter (PM) is one of the European's most problematic pollutants in terms of human health impacts [1] and its impacts depends on the size, shape and chemical composition. Epidemiological studies have consistently shown an association between PM pollution and the number of deaths from cancer and cardiovascular and respiratory diseases [2-4].

Urban areas contain a large concentration of people and anthropogenic industrial and traffic activities. Therefore, they exhibit both the highest levels of aerosol pollution and the largest targets of impact.

As a result, many studies have focused on the study of particulate matter (PM) concentrations and physico-chemical properties in worldwide urban areas and policy makers have been obliged to regulate exposure levels.

PM pollution assumes a special importance in the Iberian Peninsula, including the Setúbal area, due to several unfavourable climatologic factors: a) high temperatures and low precipitation hinder rain scavenging and promote dust re-suspension [5], b) intense insulation supports photochemistry and secondary aerosol formation [6], c) the geographical proximity to the coast and northern Africa turns sea salt and mineral dust into frequently important contributors to the PM load [7, 8] and d) PM health effects are worsened in the warmer climates of southern Europe [9].

Setúbal is an area of special concern because a high-density urban region coexists with heavy industry, harbours and protected natural areas. Therefore, national and regional authorities need a correct knowledge on aerosol characteristics in order to develop control strategies that are effective and cost acceptable.

The present work was developed within the project $\mathrm{PM}_{\text {fugitive }}$ and intends to study the aerosol composition discriminated by size, seasonal trends, formation mechanisms and emission sources in this particular urban area.

\section{Methodology}

\subsection{Sampling location}

This study was performed in the urban area of Setúbal, which is located in the west of Portugal, on the Atlantic Ocean coast at the point where the river Sado flows into the Atlantic.

Setúbal is a high-density urban region (124,555 inhabitants), that coexists with industry (power plant, paper mill, cement, pesticides and fertilized 
productions), a harbour and protected natural areas (Sado Estuary and Arrábida park that are part of the protected area Natura 2000 Network).

PM sampling was carried out in the Quebedo station $\left(38^{\circ} 31^{\prime} 27^{\prime \prime} \mathrm{N}\right.$; $8^{\circ} 53^{\prime} 39^{\prime \prime} \mathrm{W}$ ), which belongs to the Portuguese Environmental Agency Air Quality Monitoring Network and is classified as an urban traffic station (UT).

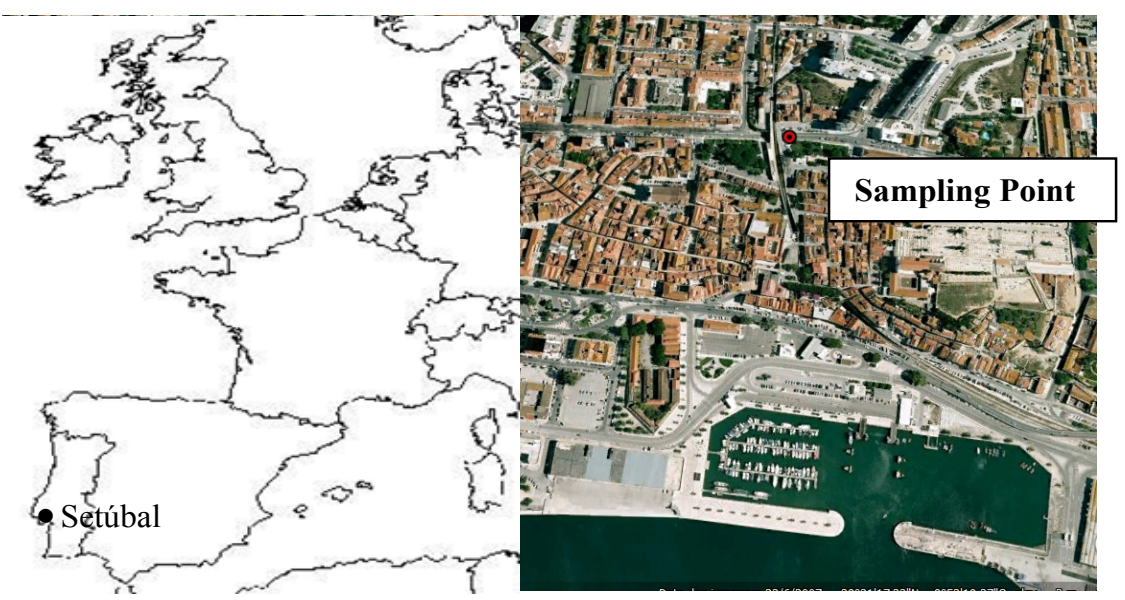

Figure 1: Location of the city of Setúbal and the sampling site (Quebedo).

\subsection{Sampling}

During the year 2011, two sampling campaigns of 2 weeks each were performed: one in winter (17-31 January) and the other one in summer (19 August2 September).

Sampling was done with a low volume Gent collector, provided with a $\mathrm{PM}_{10}$ pre-impactor stage and with a Stacked Filter Unit (SFU). The SFU carried, in two different stages, two $47 \mathrm{~mm}$ Nuclepore polycarbonate filters. Air was sampled at a rate of 15-16 L.min ${ }^{-1}$, which allowed the collection of particles with aerodynamic diameter (AD) between 2.5 and $10 \mu \mathrm{m}$ in the first stage and particles with $\mathrm{AD}<2.5 \mu \mathrm{m}$ in the second stage [10].

Sampling was performed in 12 hour periods during the day and during the night.

\subsection{Gravimetric analysis}

Filters were weighed using a Mettler Toledo balance with $0.1 \mu \mathrm{g}$ readability, placed in a controlled clean room (class 10 000).

Filter mass before and after sampling was obtained as the average of three measurements, when observed variations were less than $5 \%$. 
The exposed filters were cut into two parts: one was analyzed by Instrumental Neutron Activation Analysis using the $\mathrm{k}_{0}$ methodology ( $\mathrm{k}_{0}$-INAA) for the determination of chemical elements and the other by Ion-exchange Chromatography for the measurement of water soluble ions.

\subsection{Chemical analysis- $\mathrm{k}_{0}$-INAA}

For $\mathrm{k}_{0}$-INAA, the filter half was rolled up and put into a clean thin foil of aluminium and irradiated for $5 \mathrm{~h}$ at a thermal neutron flux of $1.03 \times 10^{13} \mathrm{~cm}^{-2} \mathrm{~s}^{-1}$ in the Portuguese Research Reactor. After irradiation, the sample was removed from the aluminium foil and transferred to a polyethylene container. For each irradiated sample, two gamma spectra were measured with a hyperpure germanium detector, with an automatic sample changer: one spectra 3 days after the irradiation and the other one after 4 weeks. The $\mathrm{k}_{0}$-INAA method was used and $0.1 \% \mathrm{Au}-\mathrm{Al}$ discs were co-irradiated as comparators.

The technique has already demonstrated its potential to yield both accurate and precise results on multi-elemental measurements of APM $[11,12]$.

Blank Nuclepore filters were treated the same way as regular samples. All measured species were very homogeneously distributed; therefore concentrations were corrected by subtracting the filter blank contents.

\subsection{Chemical analysis: Ion Chromatography}

Samples and blanks filters were extracted with $5 \mathrm{~mL}$ of ultrapure water using an ultrasonic bath (Branson 3200) for $45 \mathrm{~min}$ and the extract was filtered through a pre-washed Whatman 41 filter. This methodology was adapted from EMEP report [13].

The extracted liquid filtered was then analysed by Ion Chromatography (IC). The IC measurements of the samples were performed in an ion chromatograph Dionex $^{\circledR}$ DX500 system with conductivity detection (CD20), equipped with Peaknet $^{\mathbb{R}}$ software. In the anionic mode the chromatograph was equipped with an isocratic pump IP20, an anion pre-column IonPack AG14 4x50 mm, an analytical column IonPack AS14 4x250 mm, an anion suppressor ASRSR -Ultra $4 \mathrm{~mm}$. The eluent was a $3.5 \mathrm{mmol} \mathrm{dm} \mathrm{Na}_{2} \mathrm{CO}_{3}+1 \mathrm{mmol} \mathrm{dm}{ }^{-3} \mathrm{NaHCO}_{3}$ buffer solution at a flow rate of $1.2 \mathrm{~mL}$.min-1. Cations were analyzed using a column guard Ion Pack CG12, an Ion Pack CS12 column and a CSRS 300-II-4mm cation suppressor. The eluent was a methane sulfonic acid $20 \mathrm{mM}$ solution with a flow

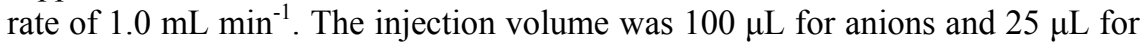
cations.

The measurements of the samples were performed after the daily calibration of the chromatograph system using measurements of calibration standards mass concentrations fit for the application of the linear regression model.

Five cations $\left(\mathrm{Na}^{+}, \mathrm{NH}_{4}^{+}, \mathrm{K}^{+}, \mathrm{Mg}^{2+}\right.$ and $\left.\mathrm{Ca}^{2+}\right)$ and three anions $\left(\mathrm{Cl}^{-}, \mathrm{NO}_{3}{ }^{-}\right.$and $\mathrm{SO}_{4}{ }^{2-}$ ) were analyzed. 


\section{Results and discussion}

\subsection{Total mass concentrations}

$\mathrm{PM}_{2.5}$ and $\mathrm{PM}_{2.5-10}$ total mass concentrations measured during the sampling campaign are presented in Figure 2. Values are discriminated by season and daily period.

Fine particulate mass concentration varied between 2.0 and $35 \mu \mathrm{g} . \mathrm{m}^{-3}$ in winter and in summer between 4.0 and $21 \mu \mathrm{g} . \mathrm{m}^{-3}$ and presented a mean value of $12.7 \mu \mathrm{g} . \mathrm{m}^{-3}$ and $9.9 \mu \mathrm{g} . \mathrm{m}^{-3}$, respectively (Table 1). Mann Whitney U-test showed that $\mathrm{PM}_{2.5}$ total mass concentration did not significantly differed between seasons $(\mathrm{p}=0.26)$. For coarse fraction, considerably high concentrations were obtained during the summer $\left(16 \mu \mathrm{g} \cdot \mathrm{m}^{-3}\right)$ comparing with the winter $\left(12 \mu \mathrm{g} \cdot \mathrm{m}^{-3}\right)$, probably due to higher re-suspension conditions that occur during the dry season.

Significant differences were not found between day and night periods both for fine $(\mathrm{p}=0.98)$ and coarse $(\mathrm{p}=0.94)$ fractions.

The European Directive 2008/50/EC of 21 May 2008 [14] on ambient air quality and cleaner air for Europe established for $\mathrm{PM}_{10}$ an annual limit value of $40 \mu \mathrm{g} \cdot \mathrm{m}^{-3}$ and a 24 hour limit value of $50 \mu \mathrm{g} \cdot \mathrm{m}^{-3}$ (which should not be exceeded more than 35 times in one year). Besides the fact that the amount of sampling days has been insufficient to perform a legal evaluation, results indicate that the concentrations measured during the sampling campaigns did not exceeded both the annual and the daily $\mathrm{PM}_{10}$ standards. $\mathrm{PM}_{10}$ average concentration determined

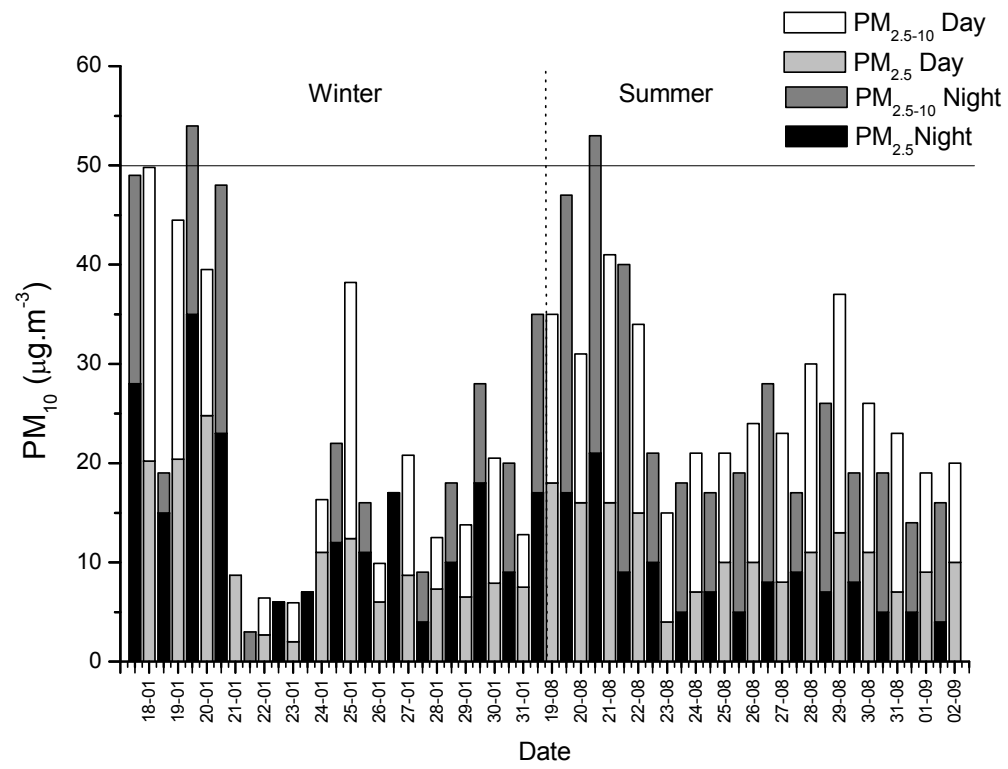

Figure 2: $\quad$ Day and night $\mathrm{PM}_{2.5}, \mathrm{PM}_{2.5-10}$ and $\mathrm{PM}_{10}$ concentrations measured in the urban station of Quebedo during the winter and summer periods. Values are in $\mu \mathrm{g} . \mathrm{m}^{-3}$. 
gravimetrically during the studied period was $25 \pm 13 \mu \mathrm{g} \cdot \mathrm{m}^{-3}$ and the $24 \mathrm{~h}$ limit value was exceeded in two nights but not in the correspondent $24 \mathrm{~h}$ periods.

The same directive established two stages for $\mathrm{PM}_{2.5}$ annual limit value concentrations. Stage 1 indicates that the annual limit value for this pollutant is $25 \mu \mathrm{g} \cdot \mathrm{m}^{-3}$ and that the date by which the limit value is to be attained is 1 January 2015. In Stage 2, the annual limit value is set at $20 \mu \mathrm{g} \cdot \mathrm{m}^{-3}$ and is to be attained by 1 January 2020 [14]. $\mathrm{PM}_{2.5}$ average concentration was $11.3 \pm 6.6 \mu \mathrm{g} . \mathrm{m}^{-3}$, which indicates that both target values were not exceeded during the sampling campaigns.

\subsection{PM chemical composition}

Table 1 presents the average concentration of water soluble ions and elements discriminated by granulometry, season and daily period. Results show that the most abundant species in $\mathrm{PM}_{2.5}$ were $\mathrm{SO}_{4}{ }^{2-}, \mathrm{NO}_{3}{ }^{-}$and $\mathrm{NH}_{4}{ }^{+}$, which are secondary aerosols that result essentially from industry and traffic. In the coarse fraction the water soluble ions $\mathrm{Cl}^{-}$and $\mathrm{Na}^{+}$, associated with the sea salt spray, and $\mathrm{Ca}^{2+}$, which results in general from the soil, also presented high concentrations.

Mann Whitney U-test demonstrated that only $\mathrm{Ca}^{2+}$, in both fractions, and $\mathrm{NH}_{4}{ }^{+}$, in the coarse fraction, presented significant differences between day and night. $\mathrm{Ca}^{2+}$ presented higher concentrations during the day probably due to the re-suspension of dust associated with traffic. $\mathrm{NH}_{4}^{+}$presented higher concentrations during the night.

Table 1: $\quad$ PM (in $\mu \mathrm{g} . \mathrm{m}^{-3}$ ), water soluble ions (in $\mathrm{ng} \cdot \mathrm{m}^{-3}$ ) and element (in ng. $\mathrm{m}^{-3}$ ) average concentrations discriminated by granulometry, season and daily period in the urban station of Quebedo.

\begin{tabular}{|c|c|c|c|c|c|c|c|c|c|c|c|c|c|c|}
\hline & \multicolumn{2}{|c|}{ All Data (Winter + Summer) } & \multicolumn{6}{|c|}{ Winter $^{\mathrm{a}}$} & \multicolumn{6}{|c|}{ Summer $^{\mathrm{b}}$} \\
\hline & \multirow{2}{*}{$\mathrm{PM}_{2.5}$} & \multirow{2}{*}{$\mathrm{PM}_{2.5-10}$} & \multicolumn{3}{|c|}{$\mathrm{PM}_{2.5}$} & \multicolumn{3}{|c|}{$\mathrm{PM}_{2.5-10}$} & \multicolumn{3}{|c|}{$\mathrm{PM}_{2.5}$} & \multicolumn{3}{|c|}{$\mathrm{PM}_{2.5-10}$} \\
\hline & & & Total & Day & Night & Total & Day & Night & Total & Day & Night & Total & Day & Night \\
\hline PM & 11 & 14 & 13 & 10 & 15 & 12 & 11 & 12 & 9.9 & 11 & 8.7 & 16 & 16 & 17 \\
\hline $\mathrm{Cr}$ & 195 & 971 & 195 & 144 & 234 & 444 & 441 & 416 & 195 & 220 & 168 & 1479 & 1099 & 1886 \\
\hline $\mathrm{NO}_{3}{ }^{-}$ & 1065 & 1071 & 1624 & 1082 & 2057 & 858 & 811 & 847 & 487 & 582 & 392 & 1285 & 1241 & 1333 \\
\hline $\mathrm{SO}_{4}{ }^{2-}$ & 1225 & 392 & 907 & 791 & 964 & 319 & 296 & 322 & 1554 & 1490 & 1618 & 465 & 372 & 564 \\
\hline $\mathrm{Na}^{+}$ & 239 & 831 & 75 & 70 & 74 & 340 & 317 & 341 & 387 & 419 & 353 & 1305 & 1055 & 1572 \\
\hline $\mathrm{NH}_{4}^{+}$ & 519 & 53 & 619 & 443 & 753 & 62 & 48 & 72 & 419 & 419 & 418 & 45 & 29 & 61 \\
\hline $\mathrm{K}^{+}$ & 126 & 74 & 187 & 137 & 224 & 66 & 63 & 64 & 64 & 57 & 72 & 81 & 49 & 116 \\
\hline $\mathrm{Mg}^{2+}$ & 23 & 86 & 9.9 & 9.5 & 9.7 & 44 & 43 & 41 & 37 & 41 & 33 & 128 & 111 & 146 \\
\hline $\mathrm{Ca}^{2+}$ & 210 & 836 & 191 & 210 & 150 & 948 & 1126 & 708 & 225 & 266 & 177 & 724 & 786 & 659 \\
\hline As & 0.46 & 0.17 & 0.63 & 0.62 & 0.59 & 0.16 & 0.16 & 0.14 & 0.042 & 0.041 & 0.045 & 0.22 & 0.17 & 0.32 \\
\hline $\mathrm{Ce}$ & 0.35 & 0.28 & 0.35 & 0.34 & 0.30 & 0.25 & 0.17 & 0.32 & 0.35 & 0.38 & 0.31 & 0.44 & 0.44 & $<\mathrm{dl}$ \\
\hline $\mathrm{Co}$ & 0.093 & 5.2 & 0.13 & 0.12 & 0.11 & 0.050 & 0.044 & 0.050 & 0.067 & 0.069 & 0.066 & 19 & 6.2 & 37 \\
\hline $\mathrm{Cr}$ & 3.5 & 7.9 & 1.3 & 0.92 & 1.6 & 5.1 & 4.6 & 5.2 & 4.4 & 4.9 & 4.0 & 13 & 13 & 14 \\
\hline Cs & 0.68 & 0.062 & 0.062 & 0.056 & 0.053 & 0.062 & 0.042 & $<\mathrm{dl}$ & 1.1 & 0.074 & 2.1 & $<\mathrm{dl}$ & $<\mathrm{dl}$ & $<\mathrm{dl}$ \\
\hline $\mathrm{Fe}$ & 138 & 286 & 153 & 148 & 147 & 294 & 325 & 232 & 121 & 138 & 100 & 254 & 293 & 201 \\
\hline $\mathrm{K}$ & 137 & 99.0 & 184 & 144 & 212 & 89 & 93 & 78 & 62 & 62 & 61 & 119 & 106 & 133 \\
\hline $\mathrm{La}$ & 0.062 & 0.15 & 0.059 & 0.060 & 0.053 & 0.093 & 0.092 & 0.086 & 0.067 & 0.065 & 0.071 & 0.23 & 0.23 & 0.23 \\
\hline $\mathrm{Na}$ & 194 & 697 & 66 & 57 & 70 & 302 & 281 & 303 & 321 & 348 & 293 & 1121 & 852 & 1410 \\
\hline $\mathrm{Sb}$ & 0.64 & 0.71 & 0.83 & 0.76 & 0.83 & 0.95 & 1.1 & 0.73 & 0.43 & 0.41 & 0.44 & 0.23 & 0.26 & 0.18 \\
\hline $\mathrm{Sc}$ & 0.015 & 0.050 & 0.009 & 0.008 & 0.010 & 0.025 & 0.023 & 0.020 & 0.021 & 0.025 & 0.018 & 0.064 & 0.072 & 0.059 \\
\hline $\mathrm{Se}$ & 0.29 & 0.072 & 0.30 & 0.18 & 0.37 & 0.072 & 0.014 & 0.10 & 0.29 & 0.24 & 0.34 & $<\mathrm{dl}$ & $<\mathrm{dl}$ & $<\mathrm{dl}$ \\
\hline $\mathrm{Sm}$ & 0.010 & 0.035 & 0.0067 & 0.0062 & 0.0066 & 0.017 & 0.017 & 0.015 & 0.017 & 0.020 & 0.013 & 0.069 & 0.033 & 0.11 \\
\hline $\mathrm{Zn}$ & 11.0 & 13.9 & 13 & 14 & 12 & 13 & 12 & 14 & 8.4 & 8.9 & 7.9 & 20 & 20 & $<\mathrm{dl}$ \\
\hline
\end{tabular}


In summer, significant high concentrations were registered 1) for $\mathrm{SO}_{4}{ }^{2-}$, due to the strong solar radiation, increasing both temperature and the formation of $\mathrm{OH}$ radicals, promoting therefore the formation of secondary sulphates; 2) for La and $\mathrm{Sm}$ in $\mathrm{PM}_{2.5-10}$, which are associated with the increase of dust re-suspension in the dry season and 3) for $\mathrm{NO}_{3}{ }^{-}$, in the coarse fraction. In this size range, $\mathrm{NO}_{3}{ }^{-}$ is partly attributed to the reaction of gaseous $\mathrm{HNO}_{3}$ with mineral species, such as calcium carbonate and with sea-salt to form $\mathrm{Ca}\left(\mathrm{NO}_{3}\right)_{2}$ and $\mathrm{NaNO}_{3}$, respectively. These reactions are predominant in the warm season, whereas in the winter $\mathrm{NO}_{3}{ }^{-}$ reacts preferentially with $\mathrm{NH}_{3}$ to form $\mathrm{NH}_{4} \mathrm{NO}_{3}$ [15]. Therefore, in winter significant high concentrations of $\mathrm{NO}_{3}{ }^{-}$in the fine fraction were observed. $\mathrm{K}$ and $\mathrm{Sb}$ in both fractions and As in fine fraction also presented higher concentrations in winter than in summer as result of lower mixing heights, that inhibit the dispersion of pollutants, and high emissions of anthropogenic elements associated with combustion processes and wood burning.

\subsection{Source apportionment}

\subsubsection{Fine and coarse contribution to $\mathrm{PM}_{10}$}

Fine and coarse contribution to $\mathrm{PM}_{10}$ has commonly been used as a first step in attempting to identify natural and anthropogenic sources of particles. Wilcoxon Matched Pairs Test and Figure 3 show that $\mathrm{Cl}^{-}, \mathrm{Mg}^{2+}, \mathrm{Na}^{+}, \mathrm{Ca}^{2+}, \mathrm{Cr}, \mathrm{Fe}, \mathrm{La}, \mathrm{Sc}$ and $\mathrm{Sm}$ presented high concentrations for coarse fraction, whereas $\mathrm{Ce}, \mathrm{K}, \mathrm{K}^{+}$, As, $\mathrm{SO}_{4}{ }^{2-}, \mathrm{Se}, \mathrm{NH}_{4}{ }^{+}$and $\mathrm{Cs}$ were predominately in the fine fraction. $\mathrm{Cl}^{-}, \mathrm{Mg}^{2+}$ and $\mathrm{Na}^{+}$were emanated from the ocean; $\mathrm{Ca}^{2+}, \mathrm{Cr}, \mathrm{Fe}, \mathrm{La}, \mathrm{Sc}$ and $\mathrm{Sm}$ reflected a soil contribution and $\mathrm{Ce}, \mathrm{K}, \mathrm{K}^{+}, \mathrm{As}, \mathrm{SO}_{4}{ }^{2-}, \mathrm{Se}, \mathrm{NH}_{4}{ }^{+}$and $\mathrm{Cs}$ probably resulted from anthropogenic activities. $\mathrm{NO}_{3}{ }^{-}, \mathrm{Sb}$ and $\mathrm{Zn}$ did not present significant differences between fine and coarse fractions.

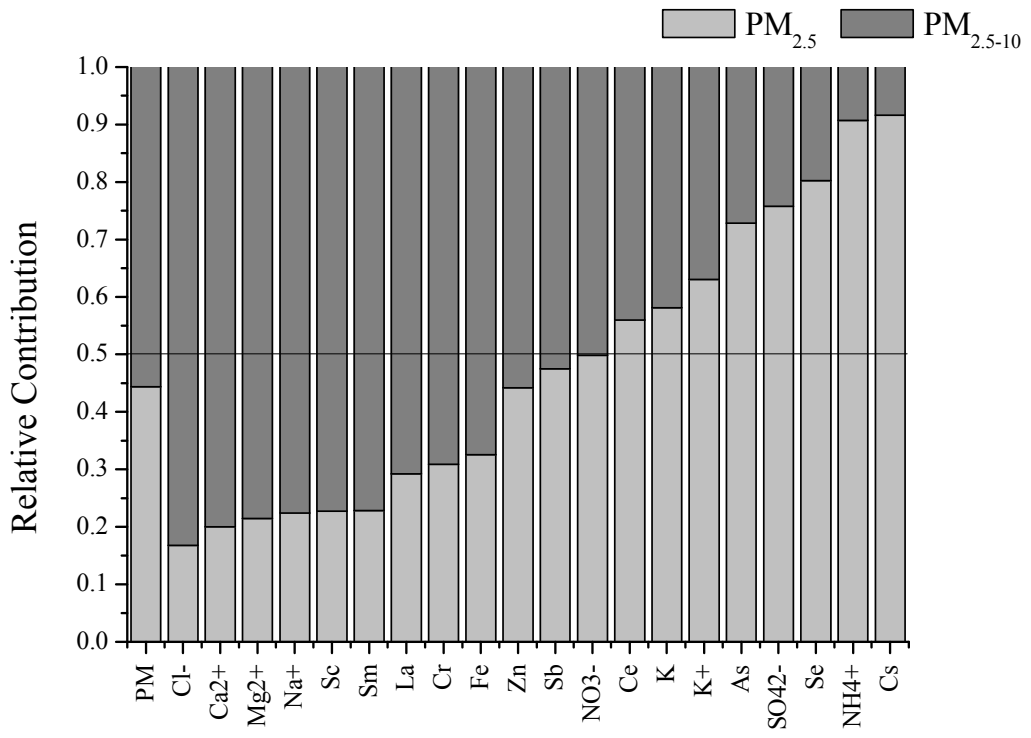

Figure 3: Relative contribution of $\mathrm{PM}_{2.5}$ and $\mathrm{PM}_{2.5-10}$ to $\mathrm{PM}_{10}$ levels. 
The highest difference between winter and summer, for the fine and coarse contribution to $\mathrm{PM}_{10}$, was observed for $\mathrm{NO}_{3}^{-}$. In winter $\mathrm{NO}_{3}{ }^{-}$is predominantly associated with the fine fraction $\left(\mathrm{PM}_{2.5}-1624 \mathrm{ng} . \mathrm{m}^{-3}\right.$ and $\left.\mathrm{PM}_{2.5-10}-858 \mathrm{ng} \cdot \mathrm{m}^{-3}\right)$ (see table 1), because it is in $\mathrm{NH}_{4} \mathrm{NO}_{3}$ form, whereas in the summer $\mathrm{NO}_{3}{ }^{-}$is principally in the coarse fraction $\left(\mathrm{PM}_{2.5}-487 \mathrm{ng} \cdot \mathrm{m}^{-3}\right.$ and $\left.\mathrm{PM}_{2.5-10}-1285 \mathrm{ng} \cdot \mathrm{m}^{-3}\right)$ due to its reactions with mineral species and sea-salt.

\subsubsection{Enrichment factors}

The crustal enrichment factor method has been used as an attempt to evaluate the strength of the crustal and non-crustal origin of the elements. Enrichment factors, using $\mathrm{Sc}$ as a crustal reference element $\left(\mathrm{EF}_{\mathrm{Sc}}\right)$, were calculated based on eqn. (1) and using Mason and Moore [16] soil composition.

$$
E F_{S c}=\frac{\left(\frac{[X]}{[S c]}\right)_{P M}}{\left(\frac{[X]}{[S c]}\right)_{\text {Soil }}}
$$

Given the local variation in soil composition, $\mathrm{EF}_{\mathrm{Sc}}>10$ suggests that a significant fraction of the element is come from by non-crustal sources, while if $\mathrm{EF}$ is lower than 10 , the element $\mathrm{X}$ is considered to have a mainly crustal origin [17].

Figure 4 shows that in both fractions the elements $\mathrm{Na}, \mathrm{Cr}, \mathrm{As}, \mathrm{Sb}$, Se and $\mathrm{Zn}$ presented high $\mathrm{EF}_{\mathrm{Sc}}$, suggesting their non-crustal origin. The elements $\mathrm{As}, \mathrm{Sb}, \mathrm{Se}$ and $\mathrm{Zn}$ are usually associated with coal combustion, incineration and traffic, whereas $\mathrm{Na}$ results from the sea salt spray.

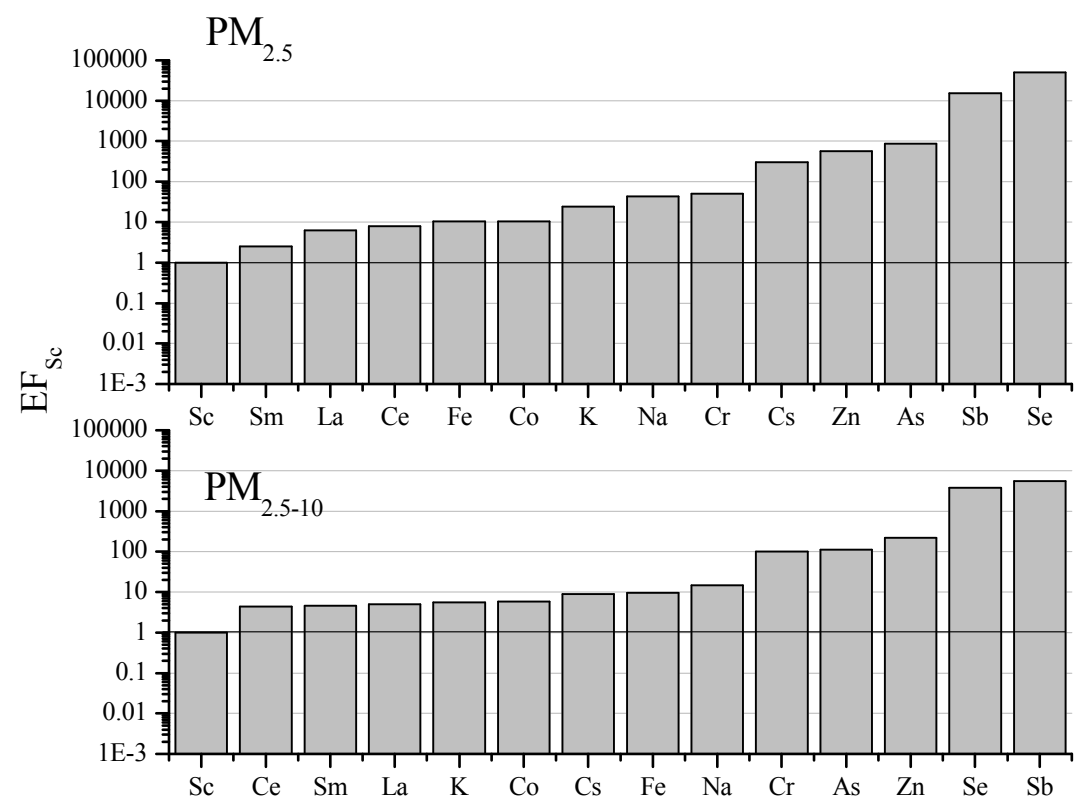

Figure 4: Enrichment factors using Sc as a reference element and Mason and Moore soil composition. 
The elements $\mathrm{Fe}, \mathrm{La}, \mathrm{Sm}, \mathrm{Sc}, \mathrm{Co}$ and $\mathrm{Ce}$ presented $\mathrm{EF}_{\mathrm{Sc}}$ lower than 10 for $\mathrm{PM}_{2.5}$ and $\mathrm{PM}_{2.5-10}$ fractions, suggesting a natural mineral origin for these elements.

\subsubsection{Principal component analysis}

Sources categories for $\mathrm{PM}_{2.5}$ and $\mathrm{PM}_{2.5-10}$ constituents were identified by means of principal component factor analysis (PCA) using STATISTICA software.

This was performed by utilising the orthogonal transformation method with Varimax rotation and retention of principal components whose eigenvalues were greater than unity. Factor loadings indicate the correlation of each pollutant species with each component and are related to the source emission composition [18].

Only the species quantified in more than $80 \%$ of the samples were retained for PCA analysis.

PCA applied to the fine and coarse particulate compounds identified four main chemical profiles sources contributing for both fractions (Table 2).

Table 2: VARIMAX normalized rotated factor loading and communalities obtained in PCA applied to $\mathrm{PM}_{2.5}$ and $\mathrm{PM}_{2.5-10}$.

\begin{tabular}{lccccc}
\hline \multicolumn{1}{c}{ PM $_{2.5}$} & $\begin{array}{c}\text { PC1 } \\
\text { Traffic }\end{array}$ & $\begin{array}{c}\text { PC2 } \\
\text { Sec. }\end{array}$ & $\begin{array}{c}\text { PC3 } \\
\text { Sea }\end{array}$ & $\begin{array}{c}\text { PC4 } \\
\text { Soil }\end{array}$ & Comun. \\
\hline $\mathrm{Na}^{+}$ & & & $\mathbf{0 . 9 7}$ & & 0.99 \\
$\mathrm{NH}_{4}{ }^{+}$ & & $\mathbf{0 . 9 6}$ & & & 0.97 \\
$\mathrm{Mg}^{2+}$ & -0.61 & & $\mathbf{0 . 7 4}$ & & 1.00 \\
$\mathrm{Ca}^{2+}$ & & & & $\mathbf{- 0 . 9 0}$ & 0.87 \\
$\mathrm{Cl}^{-}$ & & 0.44 & $\mathbf{0 . 6 8}$ & & 0.87 \\
$\mathrm{NO}_{3}{ }^{-}$ & & $\mathbf{0 . 8 8}$ & & & 0.93 \\
$\mathrm{SO}_{4}{ }^{2-}$ & & $\mathbf{0 . 7 1}$ & 0.45 & -0.29 & 0.96 \\
$\mathrm{As}$ & $\mathbf{- 0 . 9 9}$ & & & & 1.00 \\
$\mathrm{Fe}$ & & 0.31 & & $\mathbf{- 0 . 8 7}$ & 0.96 \\
$\mathrm{~K}$ & & $\mathbf{0 . 8 1}$ & & -0.47 & 0.94 \\
$\mathrm{La}$ & $\mathbf{- 0 . 9 9}$ & & & & 1.00 \\
$\mathrm{Sb}$ & $\mathbf{- 0 . 9 9}$ & & & & 1.00 \\
$\mathrm{Sc}$ & $\mathbf{- 0 . 9 9}$ & & & & 1.00 \\
$\mathrm{Zn}$ & $\mathbf{- 0 . 9 0}$ & & & & 0.88 \\
& & & & & \\
\hline \% Var Expl. & 37.14 & 23.31 & 15.90 & 13.73 & 90.09 \\
\hline
\end{tabular}

\begin{tabular}{lccccc}
\hline \multicolumn{1}{c}{$\mathrm{PM}_{2.5-10}$} & $\begin{array}{c}\text { PC1 } \\
\text { Traffic }\end{array}$ & $\begin{array}{c}\text { PC2 } \\
\text { Soil }\end{array}$ & $\begin{array}{c}\text { PC3 } \\
\text { Sea }\end{array}$ & $\begin{array}{c}\text { PC4 } \\
\text { Sec. }\end{array}$ & Comun. \\
\hline $\mathrm{Na}^{+}$ & & & $\mathbf{0 . 9 7}$ & & 0.98 \\
$\mathrm{NH}_{4}{ }^{+}$ & 0.29 & & & $\mathbf{0 . 9 0}$ & 0.93 \\
$\mathrm{Mg}^{2+}$ & 0.57 & & $\mathbf{0 . 7 5}$ & 0.25 & 0.99 \\
$\mathrm{Ca}^{2+}$ & & $\mathbf{0 . 9 5}$ & & 0.21 & 0.98 \\
$\mathrm{Cl}^{-}$ & & & $\mathbf{0 . 9 8}$ & & 0.98 \\
$\mathrm{NO}_{3}{ }^{-}$ & & 0.53 & 0.34 & $\mathbf{0 . 6 8}$ & 0.89 \\
$\mathrm{SO}_{4}{ }^{2-}$ & & 0.31 & 0.21 & $\mathbf{0 . 8 3}$ & 0.86 \\
$\mathrm{As}$ & $\mathbf{0 . 9 9}$ & & & & 1.00 \\
$\mathrm{Cr}$ & $\mathbf{0 . 9 9}$ & & & & 0.99 \\
$\mathrm{Fe}$ & & $\mathbf{0 . 9 5}$ & & & 0.95 \\
$\mathrm{~K}$ & & $\mathbf{0 . 9 4}$ & & 0.29 & 0.97 \\
$\mathrm{La}$ & $\mathbf{0 . 9 9}$ & & & & 1.00 \\
$\mathrm{Sb}$ & $\mathbf{0 . 9 9}$ & & & & 1.00 \\
$\mathrm{Sm}$ & $\mathbf{0 . 9 9}$ & & & & 1.00 \\
$\mathrm{Zn}$ & $\mathbf{0 . 9 4}$ & & 0.28 & & 0.98 \\
\hline \% Var Expl. & 42.18 & 21.49 & 18.32 & 14.69 & 96.68 \\
\hline
\end{tabular}

Only factor loadings with absolute values greater than 0.2 are presented and factor loadings with absolute values greater than 0.65 are presented in bold. Percentage of variance explained for each factor is presented.

The first factor was correlated with As, La, Sb, Sc and $\mathrm{Zn}$, which are associated with coal combustion and traffic (mainly tires and brake wear rather than combustion processes). The main components defining the second factor in $\mathrm{PM}_{2.5}$ and the fourth factor in $\mathrm{PM}_{2.5-10}$ were $\mathrm{SO}_{4}{ }^{2-}, \mathrm{NH}_{4}{ }^{+}$and $\mathrm{NO}_{3}{ }^{-}$which derived from gas to particle conversion processes of products of the $\mathrm{SO}_{2}$ oxidation and 
$\mathrm{NH}_{3}$ neutralization and from gas to particle conversion processes of products of the NOx oxidation, which was expected to result mainly from vehicle exhaust. In fine fraction, $\mathrm{K}$ also correlated with this factor. The third factor represented the marine aerosol, as deduced from the high $\mathrm{Na}^{+}, \mathrm{Cl}^{-}$and $\mathrm{Mg}^{2+}$ factor loadings. The fourth factor in $\mathrm{PM}_{2.5}$ and second factor in $\mathrm{PM}_{2.5-10}$ represented the crustal contribution, since it is defined by typical soil elements, such as $\mathrm{Ca}^{2+}, \mathrm{Fe}$ and $\mathrm{K}$.

\section{Conclusions}

In this study a chemical characterization of particulate matter $\left(\mathrm{PM}_{2.5}\right.$ and $\mathrm{PM}_{2.5-10}$ ) sampled in the urban area of Setúbal was performed and the main conclusions extracted from this work may be summarized as follows:

- $\mathrm{PM}_{2.5}$ total mass concentration did not significantly differed between seasons, whereas $\mathrm{PM}_{2.5-10}$ presented higher concentrations during the summer probably due to the higher re-suspension conditions that occur during the dry season;

- In summer significant higher concentrations were registered for $\mathrm{SO}_{4}{ }^{2-}-$ due to the stronger solar radiation, which promotes the formation of secondary sulphates; for $\mathrm{La}$ and $\mathrm{Sm}$ in $\mathrm{PM}_{2.5-10}$ - associated with the increase of the resuspension of dust in the dry season and for $\mathrm{NO}_{3}{ }^{-}$, in the coarse fraction - due to the preferential summer reaction of the gaseous $\mathrm{HNO}_{3}$ with mineral species and sea-salt to form $\mathrm{Ca}\left(\mathrm{NO}_{3}\right)_{2}$ and $\mathrm{NaNO}_{3}$, respectively.

- In winter significant high concentrations were measured for $\mathrm{K}$ and $\mathrm{Sb}$ in both fractions and for As and $\mathrm{NO}_{3}{ }^{-}$in the fine fraction, as result of lower dispersion conditions and high emissions of anthropogenic elements associated with combustion processes and wood burning.

- Significant differences were not found between day and night periods both for $\mathrm{PM}_{2.5}$ and $\mathrm{PM}_{2.5-10}$ total mass concentration. However, $\mathrm{Ca}^{2+}$, in both fractions, presented higher concentrations during the day than the night and $\mathrm{NH}_{4}{ }^{+}$, in the coarse fraction, higher concentrations during the night.

- Three approaches were used to identify emission sources: fine and coarse contribution to $\mathrm{PM}_{10}$; enrichment factors and principal component analysis. Results identified the emission sources: sea, soil, secondary aerosol, combustion and traffic.

\section{Acknowledgements}

We gratefully acknowledge the Portuguese Foundation for Science and Technology (FCT) for funding the project PMfugitive - Mitigating the Environmental and Health Impacts of Particles from Fugitive Emissions (PTDC/AAC-AMB/098825/2008) and the PhD fellowship SFRH/BD/78698 $/ 2011$. 


\section{References}

[1] European Environment Agency. EEA Technical report, No 12/2011, Air quality in Europe, 2011.

[2] HEI (Health Effects Institute). Health Effects of Outdoor Air Pollution in Developing Countries of Asia: A Literature Review. Boston, MA, 2004.

[3] U.S.EPA. Air Quality Criteria for Particulate Matter, Research Triangle Park, NC, vol-1-3, 2004.

[4] WHO, Health Risks of Particulate Matter from Long-Range Transboundary Air Pollution. WHO Regional Office for Europe, Bonn, 2006.

[5] Almeida, S.M., Pio, C.A., Freitas, M.C., Reis, M.A. \& Trancoso, M.A. Source apportionment of atmospheric urban aerosol based on weekdays/weekend variability: evaluation of road re-suspended dust contribution, Atmospheric Environment, 40, pp. 2058-2067, 2006 a.

[6] Oliveira, C., Pio, C.A., Caseiro, A., Santos, P., Nunes, T., Mao H., Luahana L. \& Sokhi, R. Road traffic impact on urban atmospheric aerosol loading at Oporto, Portugal, Atmospheric Environment 44 (26), pp. 3147 3158, 2010.

[7] Almeida, S. M., Silva, A. I., Freitas, M. C., Dzung, H. M., Caseiro, A. \& Pio, C.A. Impact of Maritime Air Mass Trajectories on the Western European Coast Urban Aerosol, Journal of Toxicology and Environmental Health, Part A: Current Issues, 76(4-5), pp. 252-262, 2013.

[8] Almeida, S. M., Freitas, M.C. \& Pio, C.A. Neutron activation analysis for identification of African mineral dust transport, Journal of Radioanalytical and Nuclear Chemistry, 276 (1), pp. 161-165, 2008.

[9] Katsouyanni, K., Touloumi, G., Samoli, E., Gryparis, A., Le Tertre, A., Monopolis, Y., Rossi, G., Zmirou, D., Ballester, F., Boumghar, A., Anderson, H.R., Wojtyniak, B., Paldy, A., Braunstein, R., Pekkanen, J., Schindler, C. \& Schwartz, J. Confounding and effect modification in the short-term effects of ambient particles on total mortality: results from 29 European cities within the APHEA2 project, Epidemiology, 12, pp. 521$531,2001$.

[10] Maenhaut, W. The Gent stacked filter unit (SFU) sampler for the collection of 199 atmospheric aerosols in two size fractions: description and instructions for installation 200 and use. IAEA CRP E4.10.08, Belgium, 1992.

[11] Almeida, S.M., Reis, M.A., Freitas, M.C. \& Pio, C.A. Quality assurance in elemental analysis of airborne particles. Nucl. Instrum. Meth. B. 207, pp. 434-446, 2003a.

[12] Almeida, S.M., Freitas, M.C., Reis, M.A. \& Pio, C.A. Quality assessment on airborne particulate matter of k0-INAA. J. Radioanal. Nucl. Chem. 257, pp. 609-613, 2003b.

[13] EMEP - Manual for sampling and chemical analysis. EMEP/CCC-Report 1/95, Revision 1/2001, 2001. 
[14] European Commission. Directive 2008/50/EC of the European Parliament and of the Council of 21 May 2008 on Ambient Air Quality and Cleaner Air for Europe. Technical Report 2008/50/EC, L152. Off. J. Eur. Comm, 2008.

[15] Almeida, S.M., Pio, C.A., Freitas, M.C., Reis, M.A., \& Trancoso M.A. Approaching PM2.5 and PM2.5 - 10 source apportionment by mass balance analysis, principal component analysis and particle size distribution. Sci. Total Environ. 368, pp. 663-674, 2006b.

[16] Mason, B. \& Moore, C.B. Principles of Geochemistry. New York: Wiley; p. $46,1982$.

[17] Torfs, K. \& Van Grieken, R. Chemical relations between atmospheric aerosols, deposition and stone decay layers on historic buildings at the Mediterranean coast. Atmospheric Environment, 31, pp. 2179-2192, 1997.

[18] Almeida S.M., Pio, C.A., Freitas, M.C., Reis, M.A. \& Trancoso, M.A. Source apportionment of fine and coarse particulate matter in a sub-urban area at the Western European coast. Atmospheric Environment; 39(3), pp. 127-238, 2005. 